American

Journal of

International

Law

VOLUME 67

1973

Published by The

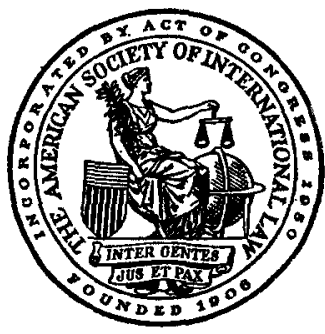

American Society of International Law 


\section{The American Society of International Law}

The American Society of International Law was organized in 1906 "to foster the study of international law and to promote the establishment and maintenance of international relations on the basis of law and justice."

The Society serves as a meeting place and forum for scholars, teachers, offcials, lawyers, and others, from some one hundred countries. In April, it holds a three-day Annual Meeting in Washington at which current problems of international law are discussed. The Society also sponsors regional meetings outside of Washington in co-operation with other institutions. Salient questions of international law and relations are considered in depth by panels and study groups organized by the Society's Board of Review and Development. Works of scholarship are often published under the Society's auspices in connection with studies sponsored by the Board.

The Society periodically issues three publications:

The American Journal of International Law, the leading journal in the field of international law, has been published since 1907. A special issue of the Journal carries the papers and discussions of the annual meeting of the Society. The Journal is distributed to all members of the Society without additional charge, and is available to non-members at a subscription rate of $\$ 30$ a year.

International Legal Materials, a bimonthly, is a unique international collection of texts of current official documents, including legislation, treaties, court decisions, and reports. Subscription rates are $\$ 15$ a year for members of the Society, $\$ 35$ for others. ${ }^{*}$

The monthly Newsletter provides members with news of the Society and other organizations in the field.

Society membership is open to all persons of whatever nationality and profession who are interested in its objectives. Dues are: regular, $\$ 25$ for residents of the United States, $\$ 10$ for non-residents; $*$ professional, $\$ 40$; intermediate, $\$ 15$; student, $\$ 7.50$. Application for membership may be made on the form printed at the back of this issue of the JournaL.

OFFICERS OF THE SOCIETY, 1973-1974

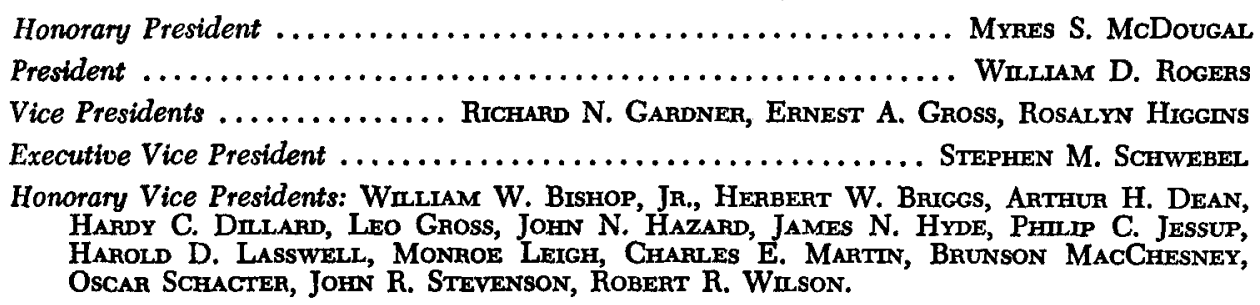

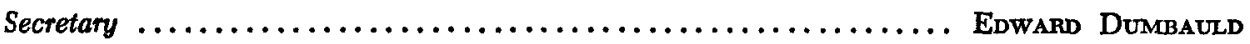

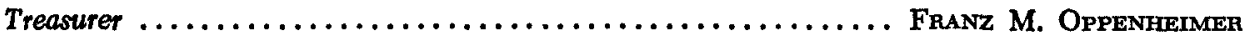

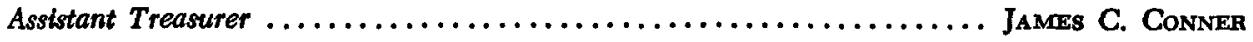

- As of January 1974, regular subscriptions for International Legal Materials will be $\$ 45$; dues for non-resident members will be $\$ 15$. 


\title{
BOARD OF EDITORS
}

\author{
Editor-in-Chief \\ Richard R. BAXTER \\ Harvard Law School
}

RICHARD B. Bilder

University of Wisconsin Law School

Thomas Buergenthal

State University of New York, Buffalo

John CAREy

New York, N. Y.

Jerome A. Cohen

Harvard Law School

Alona E. Evans

Wellesley College

Rrchard A. Falk

Princeton University

Thomas M. Franck

New York University

\section{Louis HENKIN}

Columbia University School of Law

Monroe Leigh

Washington, D. C.

Ruchard B. LILLICH

University of Virginia Law School

OLIVER J. LISSITZYN

Columbia University School of Law

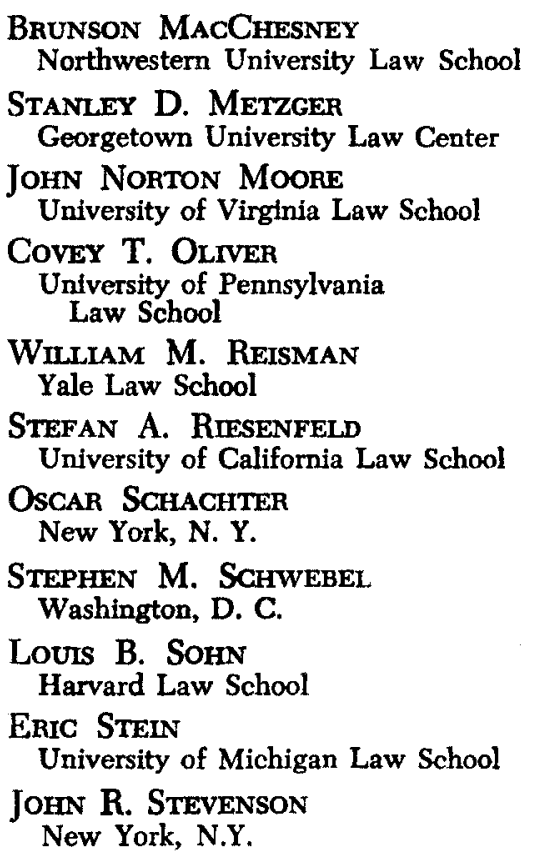

Marjonie M. Whiteman

Liberty Center, Ohio

\section{Honorary Editors}

William W. Bishop, Jr.

University of Michigan Law School

Herbert W. Briggs

Cornell University

HaRdY C. Dillard

University of Virginia Law School

LEO Gross.

Fletcher School of Law and Diplomacy, Tufts University
PHinIP C. Jessup New York, N. Y.

MYRes S. McDougal Yale Law School

Pitman B. Potter American University

JohN B. WhrtTon Princeton University

ROBERT R. WILSON

Duke University

Assistant Editor

AnNe Patricia SnMons

Editorial Assistant

Rosemary G. Conley

Assistant Editor Emerita

Eleanor H. Finch 


\section{AMERICAN JOURNAL OF \\ INTERNATIONAL LAW}

VOLUME 67

[No. 1, January 1973, pp. 1-228; No. 2, April 1973, pp. 229-422; No. 3, July 1973, pp. 423-640; No. 4, October 1973, pp. 641-840.]

The Amendments to the Rules of Procedure of the International Court of Justice Eduardo Jiménez de Aréchaga

PAGE

Poland's Western Frontier and the 1970 Treaties

Krzystof Skubiszewski 23

Berlin and the Quadripartite Agreement of 1971

Günther Doeker, Klaus Melsheimer, and Dieter Schröder

A New Legal Framework for Trade Between the United States and the Soviet Union: The 1972 US-USSR Trade Agreement Robert Starr

The Twenty-Fourth Session of the International Law Commission Richard D. Kearney

National Jurisdiction and International Responsibility: New Canadian Approaches to International Law Allan Gotlieb and Charles Dalfen

The Protection of Shareholders' Interests in the Light of the Barcelona Traction Case

F. A. Mann

After Bangladesh: The Law of Humanitarian Intervention by Military Force

Thomas M. Franck and Nigel S. Rodley

El Chamizal

Philip C. Jessup

The Admission of Judges Ad Hoc in Advisory Proceedings: Some Reflections in the Light of the Namibia Case Michla Pomerance

International Law Aspects of Repatriation of Prisoners of War during Hostilities

Richard A. Falk

Natural Justice at the United Nations: The Rhodesia Case

Michael Stephen

Alona E. Evans 641

Aircraft Hijacking: What is Being Done

Confronting Total War: A "Global" Humanitarian Policy

Jacques Freymond

International Law Aspects of Repatriation of Prisoners of War During Hostilities: A Reply Howard S. Levie

Some International Law Problems Posed by the Nationalization of the Copper Industry by Chile Francisco Orrego Vicuña

The Jurisprudence of the Foreign Claims Settlement Commission: Chinese Claims Charles Ford Redick 
Editorial Comment:

In Memoriam: Wolfgang Gaston Friedmann

John N. Hazard, Louis Henkin, and Oliver J. Lissitzyn 102

In-Flight Crime and United States Legislation Oliver J. Lissitzyn 306

Hans Kelsen: October 11, 1881-April 15, 1973

Leo Gross 491

Charles Ghequiere Fenwick: 1880-1973

Alwyn V. Freeman 501

The Doctrine of Self-executing Treaties and Community Law: A Pioneer Decision of the Court of Justice of the European Community Stefan A. Riesenfeld 504

International Terrorism and International Criminal Jurisdiction

Leo Gross

Notes and Comments:

United States Ratification of the Hague Convention on the Taking of Evidence Abroad Philip W. Amram 104

Mini-States and a More Effective United Nations

Stephen M. Schwebel 108

The Service of Professor Brunson MacChesney as Acting Editor-inChief of the Journal

Richard R. Baxter 116

Annual Meeting of the American Society of International Law

Anne Simons

U.S. International Law Digests: Some History and a New Approach Arthur W. Rovine 314

International Law as a Cultural Excrescence Alfred P. Rubin

New Student Journals

Ann Simons

Legal Aspects of the Continued Detention of Pakistani Prisoners of War by India

Howard S. Levie 512

The US-USSR Trade Agreement From a Soviet Perspective

Harold J. Berman

The Twelfth Session of the Hague Conference on Private International Law

Philip W. Amram

The Francis Déak Prizes

Anne Simons

Recent Movements toward Strengthening the International Court of Justice

Eberhard P. Deutsch

Public Debt and Sovereign Immunity: Some Considerations Pertinent to $S .566$

G. R. Delaume

\section{Correspondence:}

Letters by Thomas Ehrlich and Carl B. Spaeth to John R. Stevenson, Legal Adviser, Department of State

Teaching International Law

Alfred P. Rubin 757

Reply to Professor Marek

Bruno Simma 758

\section{Contemporary Practice of the United States Relating to Intermational}


Judicial Decisions

Book Reviews and Notes

Books Received
Alona E. Evans 127, 338, 547, 778

Leo Gross 156, 352, 759, 791

$190,386,614,824$

Official Documents:

International Court of Justice:

Rules of Court, as Amended on May 10, 1972

United States-Democratic Republic of Vietnam-Republic of Vietnam-Provisional Revolutionary Government of the Republic of South Vietnam

Agreement on Ending the War and Restoring Peace in Vietnam

Protocol concerning the Cease-fire in South Vietnam and the Joint Military Commission

Protocol concerning the Return of Captured Military Personnel and Foreign Civilians and Captured and Detained Vietnamese Civilian Personnel

Protocol concerning the International Commission of Control and Supervision

Protocol concerning the Removal, Permanent Deactivation, or Destruction of Mines in the Territorial Waters, Ports, Harbors, and Waterways of the Democratic Republic of Vietnam

Cuba-United States. Memorandum of Understanding on Hijacking of Aircraft and Vessels and Other Offenses

Act of the International Conference on Viet-Nam 620

United States: Protection of Diplomats Act

Convention on the Prevention of Marine Pollution by Dumping of Wastes and other Matter

United States-Democratic Republic of Vietnam-Republic of Vietnam-Provisional Revolutionary Government of South Vietnam. Joint Communique, June 13, 1973

Union of Soviet Socialist Republics-United States

Basic Principles on the Further Limitation of Strategic Offensive Weapons

International Legal Materials. Contents, Vol. XI, No. 5 (1972); Vol. XII, No. 1-4 (1973)

Table of Cases

Copyright (C) 1973 by The American Society of International Law Second-class postage paid at Lancaster, $\mathrm{Pa}$. 